\title{
Professional Public Relations (PR) trends and challenges
}

\author{
Ana Almansa-Martínez; Ana-Belén Fernández-Souto
}

Nota: Este artículo se puede leer en español en:

http://www.elprofesionaldelainformacion.com/contenidos/2020/may/almansa-fernandez_es.pdf

How to cite this article:

Almansa-Martínez, Ana; Fernández-Souto, Ana-Belén (2020). “Professional Public Relations (PR) trends and challenges". El profesional de la información, v. 29, n. 3, e290303.

https://doi.org/10.3145/epi.2020.may.03

Invited manuscript received on $29^{\text {th }}$ April 2020

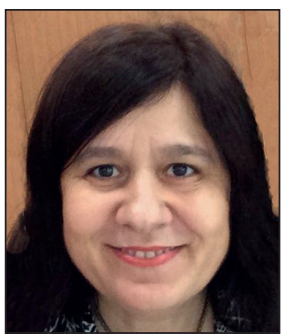

\author{
Ana Almansa-Martínez $\bowtie$ \\ https://orcid.org/0000-0003-0256-6369 \\ Universidad de Málaga \\ Facultad de Ciencias de la Comunicación \\ Departamento de Comunicación \\ Audiovisual y Publicidad \\ Campus de Teatinos. 29010 Málaga, Spain \\ anaalmansa@uma.es
}

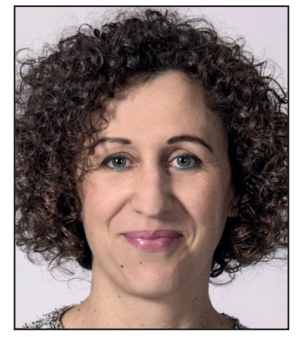

Ana-Belén Fernández-Souto https://orcid.org/0000-0003-2685-0604

Universidade de Vigo

Fac. de Ciencias Sociais e da Comunicación Dto. de Com. Audiovisual y Publicidad

Campus A Xunqueira, $\mathrm{s} / \mathrm{n}$.

36005 Pontevedra, Spain

abfsouto@uvigo.es

\begin{abstract}
There are several studies and reports that identify the challenges that Public Relations must assume in the coming years, but how will the professional field face them? Are the organizations and institutions prepared to assume the new needs that constant adaptation demands? What are the priorities that they must establish so that the profession is renewed? The profession, in order to face the challenges that the future holds in the changing society in which we live, must commit itself to training. Thanks to training, Public Relations professionals will be able to achieve a high degree of specialization in the discipline. Strategic vision, public relations (PR) assessment, commitment to quality and professional ethics, transparency, as well as inclusion and equality must be the benchmarks of the sector.
\end{abstract}

\section{Keywords}

Public Relations; PR; Challenges; Trends; Training; Professional career; Research.

\section{Introduction}

A recurring concern in all disciplines is the near future and the challenges to be taken up in order to survive. The field of public relations does not escape this concern so that, both from the academic and scientific point of view, as well as from the professional one, reflections are raised in meetings and reports on a constant basis.

Recently, the Global Alliance for Public Relations and Communication Management has indicated that it is necessary to help

"make the 2020 decade one of renewal and growth for our profession and ensure that we pass it on to future generations in the best possible way" (Dircom, 2020).

This idea of renewal and growth in the field of Public Relations has been permanent throughout its history, but it is even more important today, because our changing society requires them to be adapted to our current needs. Along these lines, last January $29^{\text {th }}$, the Institute for Public Relations (2020) published The top 14 public relations insights of 2019, in which several aspects to be faced from the professional field of public relations were identified, which clearly coincide with the results of studies carried out in our country and also on a European level; a case in point is the latest edition of the European Communication Monitor (Zerfass et Challenges: fighting disinformation, genal., 2019) on the main strategic concerns of Public Relader equality and mastering technologies tions until 2022. 
Among the many ideas that the different studies identify as challenges to be faced in the coming years, we will focus specifically on three:

- The fight against disinformation, given the invasive presence of fake news; this is a constant search for values such as transparency and responsibility.

- A greater commitment to progress towards inclusiveness with improvements in conditions for women in the workplace, where barriers and stereotypes still exist.

- And the fact that the use of technology in public relations will continue to evolve, with an increase in the analysis and measurement of results and the need to focus beyond artificial intelligence and automation, including leadership, communication, agility and creation.

This perception coincides with the study conducted by Dircom (2018), which considers that the priority issues for the profession will be the digital environment and the use of new information technologies. Despite this generalised view in professional reports, there are academics, such as Rodríguez-Fernández and Vázquez-Sande (2019), who differ -at at least in part- in considering that these challenges should not be reduced to mere technological implications either, as this would mean partially facing up to a volatile and constantly evolving reality.

How are organisations preparing to meet these PR challenges? If we accept these items as challenges of public relations in the professional field, we must ask ourselves how organizations are preparing themselves, both at a business and institutional level, to face them. To do so, we try to X-ray the reality in Spain through the main professional studios.

\section{Transparency and accountability}

It is assumed that it is the professionals with specific training who know how to best and most effectively achieve solutions to the problems that arise. According to the Informe PR 2018, the number of professional affiliations in Spain is increasing, as the overall number of employees of the top 40 firms in the sector is up from the previous year's data.

This positive figure confirms the upward trend in public relations within the field of communication, despite the fact that labour intrusion continues to be a constant. This is stated by the Asociación de la Prensa de Madrid (Madrid Press Association) (2018) in its Annual Report on the Journalistic Profession 2018, which, despite focusing on the journalistic field, covers public relations issues, since respondents are asked whether the activity in communication can be considered a journalistic activity and $54 \%$ consider it so. Furthermore, when asked about the level of studies completed by those surveyed, the Report ignores the degree itself in Advertising and Public Relations. This point of view does not coincide with other studies, such as that published by Dircom (2018), on the state of communication in Spain, which shows that most professionals are graduates or bachelors, mainly in journalism (55.6\%) and in Advertising and Public Relations (17.6\%).

It is out of the question that in all the studies it is evident that there is an important number of journalists developing professional activities in the area of Public Relations; some authors consider this fact as an intrusion, however, it is also necessary to point out that both degrees come from the area of communication, and there is also a great number of professionals practicing Public Relations with training in areas totally alien to this area, which seems more serious. In any case, it is confirmed that this intrusiveness exists, to a great extent, given the inexistence of a collegiate regulation indicating who may or may not carry out the activity of Public Relations. It is considered that organisations that are committed to training their employees invest in transparency and responsibility, which necessarily translates into a positive return in terms of the image of society itself.

\section{Training and profession}

There are undergraduate and graduate studies in Public Relations in practically the entire world. In the case of Spain, undergraduate studies are usually accompanied by another discipline of communication: advertising and Public Relations is the most widely used name, specifically in 33 universities (Rodríguez-Fernández; Barón-Dulce, 2017).

Greater diversity, if possible, occurs in the case of postgraduate studies. There is a wide range of courses on offer and the names of the master's and doctoral programs are very varied (Almansa-Martínez; Athaydes, 2012). 70\% of directors of communication in Spain have postgraduate studies (Dircom, 2018), although on most occasions they do not relate the postgraduate studies carried out to Public Relations, but refer to terms such as management (Matilla et al., 2019).

Any Public Relations professional, in order to adequately develop their work, in order to be able to relate to the public, needs to have specialized training in the discipline. 
"The commitment to training is one of the main challenges facing the profession in the future. We cannot consider the sector to be professionalized until we achieve greater quotas of training", so that "training becomes the central axis of every professional who works in communication" (Almansa-Martínez, 2015).

The Public Relations professional must be qualified to relate to the media, but also to be in charge of internal communication, crisis communication, protocol or relate to specialized audiences, lobbies, among other areas of action (Castillo-Esparcia; Guerra-Heredia; Almansa-Martínez, 2017; Castillo-Esparcia; Smolak; Lozano; Fernández-Souto, 2017). And this applies to the different spheres of action: whether in the institutional, business or social world, knowing exactly the peculiarities of each sector.

Management (or management, coordination and direction) as well as leadership capacity. The training of the Public Relations professional must focus on all these skills and abilities. And, in addition, it needs a vision of the future. Not only will they have to be proactive, but they will also have to know, at all times and in all circumstances, which tool, technique and strategy can be most effective.

The Public Relations professional needs to have a strategic vision of communication (Dircom, 2015). At the same time, they must be aware of all the tools available to them to carry out their work, whether it is a traditional or a new tool linked to ICTs. That is why the training of Public Relations professionals is dynamic, which goes through degrees and postgraduate courses, but also requires constant updates, to be able to cope with such a changing world, technologically speaking.

Another challenge for the profession is evaluation (Dircom, 2015). Organizations, at present, have the need to evaluate their communication, not only from a quantitative perspective, but also from a qualitative one. It has always been desirable to measure the results of Public Relations actions, but today it is essential, given the complexity of the supports in which the messages are distributed to reach the public. In this sense, training in evaluation should also be encouraged, in order to train the Public Relations professional in this decisive field.

In the Spanish case, there are mainly three professional associations to watch over the sector:

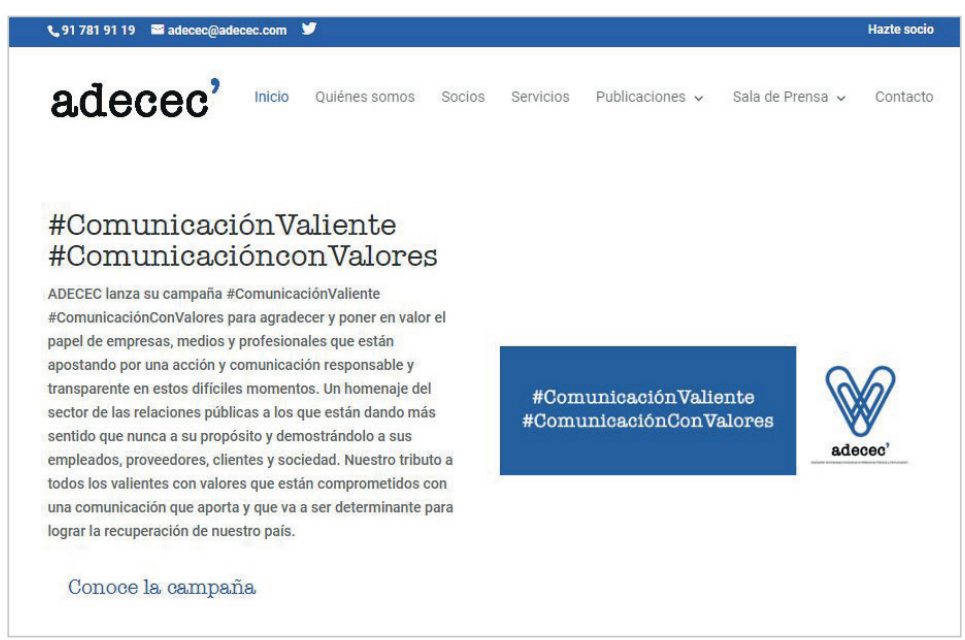

http://adecec.com

- Asociación de Directivos de Comunicación (Dircom) / Association of Communication Managers, which includes professionals from the communication departments

- Asociación de Empresas Consultoras en Relaciones Públicas y Comunicación (Adecec) / Association of Consulting Companies in Public Relations and Communication, to which Public Relations, consulting and advisory companies belong.

- Asociación de Investigadores en Relaciones Públicas (AIRP) / Association of Researchers in Public Relations, to which teachers and researchers belong.

AIRP was born in 2004 and its objectives are the improvement of the Public Relations profession, as well as its recognition:

- "Research in Public Relations.

- To provide continuous training to graduates in this discipline and to active professionals with experience in this field.

- To disseminate knowledge of Public Relations among university researchers and teachers, professionals, the media and civil society in general.

- To promote a common forum for the debate of all professionals and university academics who reflect on and research Public Relations, understood as a science.

- To promote the presence of Public Relations subjects in the curricula of the university degrees in communication sciences and other official degrees derived from the process of construction of the European Higher Education Area" (AIRP,

Organizations have a need to evaluate their communication both quantitatively and qualitatively 


\section{Inclusiveness}

There is still a long way to go, since there is a significant percentage of women doing Public Relations work $-72 \%$, according to Adecec's study (2019)- but only $24 \%$ hold management positions. This same study indicates that around $56 \%$ of the analyzed consultancy firms fail in their contribution to equality.

There are various factors responsible for this equality gap, such as the unequal distribution of family and domestic responsibilities between men and women and, according to the PwC study (2019),

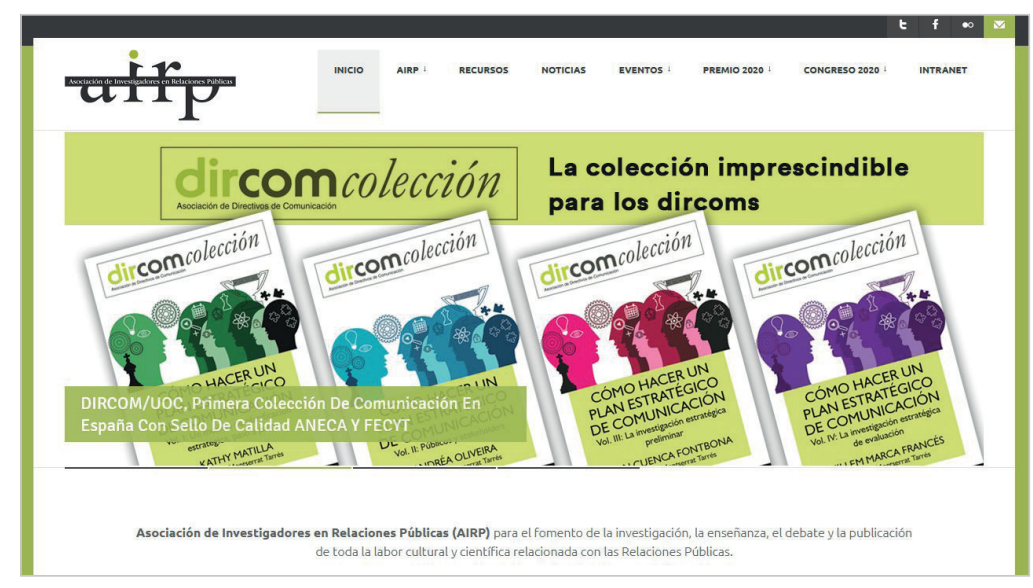

http://airrpp.org

"differences in psychological traits and non-cognitive skills of men and women, mainly differences in the propensity to take risks and negotiate."

Furthermore, this PwC report insists that Spanish women have a much higher percentage of temporary and part-time contracts than men, another evidence of the need to continue investing in equality.

In a very similar vein, Moreno, Fuentes and Khalil (2018) explain in the Gendercom study that

"the glass ceiling remains. Despite the fact that women outnumber men, we can see how their presence decreases in the highest positions and predominates in the lower ones in the hierarchy."

They explain how

"in management positions $71.3 \%$ are men and $56.1 \%$ women. That is: seven out of every ten men working in communications hold management positions" (Moreno; Fuentes; Khalil, 2018).

It seems that legislation and social pressure are not exerting enough pressure for full labour equality between men and women in our country and, as we indicated before, there is still a long way to go, despite the milestones achieved.

\section{Use of technologies}

It is clear that the use of technologies in the field of communication represents a major advance in daily work, especially in terms of access to data and its subsequent use for strategic planning and execution. The latest study by Dircom (2018) shows that organisations are preparing to

"use big data and algorithms for communication" (50.4\%),

"connect organisational and communication strategies" (46.8\%) and

"create and manage quality content that is attractive to the organisation's audiences" (40.1\%).

Taking the second theme as the backbone, it is interesting to highlight the relationship between the strategic and more operational aspects of communication. The relationship between corporate and communication strategies is a demand in the sector that has been maintained in Spain in particular, as well as in the rest of the world (Zerfass et al., 2017, 2016; Moreno; Tench; Okay, 2017; Macnamara; Zerfass, 2017).

However, despite the weight that organizations give to the use of technologies, there are studies that indicate that this is not the most worrying issue for Spanish organizations, which value more aspects related to intangible values such as reputation, transparency, honesty or credibility (Fernández-Souto; Puentes-Rivera; Vázquez-Gestal, 2019). We note, therefore, that there are different views on the subject and not all of them are in the same direction.

\section{Conclusion}

It seems clear that the future of Public Relations will increase its value, due to the growing role given to communication by organizations (Cabrera-Cabrera; Almansa-Martínez, 2016); this will lead to communication departments becoming a relevant area for companies and institutions, since they will be forced to professionalize this need.

Similarly, among the many challenges that the profession must face, we prioritize the following:

- Giving greater weight to strategic plans, so as to increase the connection between organizations and communication, which will make it possible to plan and execute quality content that is perfectly focused on specific key audiences for the issuer. When establishing these strategic plans, the collection of information from the public will be -to a large extent- determined by the use of big data and the technologies associated with the Internet. 
- Regarding the management of the profession itself, it is clear that organisations will have to focus on their specialisation. This is evident in the tendency to hire staff with higher education, preferably in communication, and in particular, trained in Public Relations. This specialisation of professionals will result in "knowhow" for organisations, which will imply an increase in their transparency and responsibility towards each of their target audiences.

- Like other professional sectors, the field of Public Relations still has a way to go in terms of equality; despite the fact that there is a majority of women developing Public Relations activities, management positions are still in male hands.

With the economic crisis of 2008, organizations understood the value of communication and Public Relations, so it is a sector that has a growing consideration within the various entities, as they have seen in their studies Dircom (2010, 2015, 2018) and Cabrera-Cabrera; Almansa-Martínez (2016). Perhaps from the current crisis, due to the Covid-19 pandemic, Public Relations will also be strengthened, because its good or bad practice can be a determining factor for the image of institutions, companies and organizations in general, as well as for citizens in general.

\section{References}

Adecec (2019). Las mujeres ocupan más del 72\% de los trabajos en comunicación y relaciones públicas y el $50 \%$ de los puestos directivos.

https://bit.ly/2zEnNB9

AIRP (2020). Objetivos. Asociación de Investigadores en Relaciones Públicas. http://airrpp.org/que-es-la-airp

Almansa-Martínez, Ana (2015). “Formación de profesionales estratégicos". Anuario de la comunicación 2015. Madrid: Dircom, p. 84.

http://www.dircom.org/publicaciones/anuario/item/7069-anuario-de-la-comunicacion-2015

Almansa-Martínez, Ana; Athaydes, Andreia (2012). “Los posgrados en Relaciones Públicas en las universidades españolas. Estudio sobre su situación y temáticas". In: La innovación en Relaciones Públicas. Barcelona: Trípodos (número especial), pp. 315-330.

Asociación de la Prensa de Madrid (2018). Informe anual de la profesión periodística 2018. Madrid: APM. https://www.apmadrid.es/publicaciones/informe-anual-de-la-profesion

Cabrera-Cabrera, Mariángeles; Almansa-Martínez, Ana (2016). “El director de relaciones públicas en las grandes empresas españolas". Revista internacional de relaciones públicas, v. 6, n. 11.

http://doi.org/10.5783/RIRP-11-2016-07-113-134

Castillo-Esparcia, Antonio; Guerra-Heredia, Sergio; Almansa-Martínez, Ana (2017). “Comunicación política y think tanks en España. Estrategias con los medios de comunicación". El profesional de la información, v. 26, n. 4.

https://doi.org/10.3145/epi.2017.jul.14

Castillo-Esparcia, Antonio; Smolak-Lozano, Emilia; Fernández-Souto, Ana-Belén (2017). “Lobby y comunicación en España. Análisis de su presencia en los diarios de referencia”. Revista latina de comunicación social, n. 72.

https://doi.org/10.4185/RLCS-2017-1192

Dircom (2010). El estado de la comunicación en España 2010. Madrid: Dircom.

http://www.dircom.org/publicaciones/estudios/item/1788-el-estado-de-la-comunicación-en-españa-2010

Dircom (2015). El estado de la comunicación en España 2015. Madrid: Dircom.

https://www.slideshare.net/txiquilla/el-estado-de-la-comunicacin-en-espaa-en-2015

Dircom (2018). El estado de la comunicación en España 2018. Madrid: Dircom.

https://envios.dircom.org/docs/ECE-2018.pdf

Dircom (2020). La Global Alliance cumple 20 años con el compromiso de seguir poniendo en valor la Comunicación y las Relaciones Públicas.

https://bit.ly/2KCiWTk

Fernández-Souto, Ana-Belén; Puentes-Rivera, Iván; Vázquez-Gestal, Montserrat (2019). “Gestión de la comunicación en las competiciones deportivas regulares: Fútbol sala, voleibol, baloncesto y balonmano en España". Retos: nuevas tendencias en educación física, deporte y recreación, n. 36.

https://dialnet.unirioja.es/descarga/articulo/6770636.pdf

Institute for Public Relations (2020). The top 14 public relations insights of 2019.

https://bit.ly/35aNeWC 
Macnamara, Jim; Zerfass, Ansgar (2017). "Evaluation stasis continues in PR and corporate communication: Asia Pacific insights into causes". Communication research and practice, v. 3, n. 4.

https://doi.org/10.1080/22041451.2017.1275258

Matilla, Kathy; Miranda, Thais; Compte-Pujol, Marc; Oliveira, Andreia (2019). "La formación de postgrado de los directores de comunicación españoles". Revista internacional de investigación en comunicación aDResearch ESIC, v. 19, n. 19. https://doi.org/10.7263/adresic-019-02

Moreno, Ángeles; Fuentes-Lara, Cristina; Khalil, Nadia (2018). Gendercom. Brechas y oportunidades de género en la profesión de gestión de la comunicación en España. Madrid: Asociación de Directivos de Comunicación. ISBN: 97884 09076673

Moreno, Ángeles; Tench, Ralph; Okay, Ayla (2017). "Re-fuelling the talent tank. A qualitative study of key deficiencies, future needs, and life-long learning needs of communication management professionals in Europe". Communication \& society, v. 30, n. 3.

https://doi.org/10.15581/003.30.3.109-127

PRnoticias (2018). Informe PR2018. Madrid: prnoticias.

https://bit.ly/2yVsOzR

PwC (2019). Análisis de la brecha salarial de género en España. Madrid: CEOE y PwC.

https://pwc.to/3aJvfb8

Rodríguez-Fernández, Leticia; Barón-Dulce, Gema (2017). “La enseñanza del área de la dirección de comunicación en los grados en publicidad y relaciones públicas". In: Los estudios universitarios especializados en comunicación en España. Barcelona: Editorial UOC, pp. 103-120. ISBN: 9788491167013

Rodríguez-Fernández, Leticia; Vázquez-Sande, Pablo (2019). "Retos y perspectivas en la comunicación organizacional". El profesional de la información, v. 28, n. 5, e280501.

https://doi.org/10.3145/epi.2019.sep.01

Zerfass, Ansgar; Moreno, Ángeles; Tench, Ralph; Verčič, Dejan; Verhoeven, Piet (2017). European communication monitor 2017. Brussels: Euprera/EACD, Quadriga Media Berlin.

https://www.communicationmonitor.eu/2017/06/04/ecm-european-communication-monitor-2017-social-botsvisualisation-hypermodernity-benchmarking-strategic-communication

Zerfass, Ansgar; Verčič, Dejan; Verhoeven, Piet; Moreno, Ángeles; Tench, Ralph (2019). European communication monitor 2019. Brussels: Euprera/EACD, Quadriga Media Berlin.

http://www.communicationmonitor.eu/wp-content/uploads/dlm_uploads/ECM19-European-CommunicationMonitor-2019.pdf

Zerfass, Ansgar; Verhoeven, Piet; Moreno, Ángeles; Tench, Ralph; Vercic, Dejan (2016). European communication monitor 2016. Brussels: Euprera/EACD, Quadriga Media Berlin.

http://www.communicationmonitor.eu/wp-content/uploads/2018/03/ECM-2016-Results-ChartVersion-EuropeanCommunication-Monitor-Trends-Strategic-Communication-Management-Corporate-Communication-Public-Relations-PR.pdf

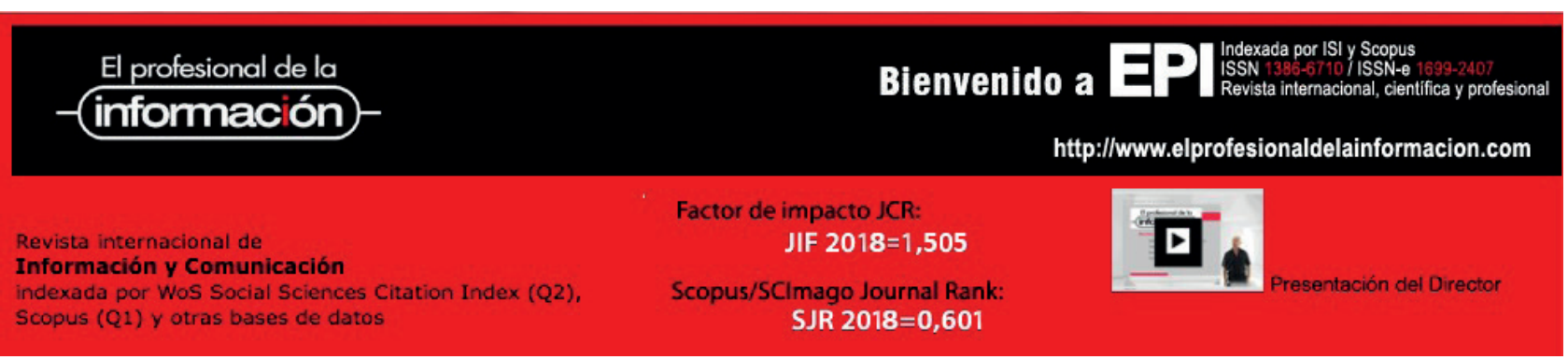

